DOI

\title{
ВИЗНАЧЕННЯ ЯКІСНОГО СКЛАДУ ТА КІЛЬКІСНОГО ВМІСТУ ГІДРОКСИКОРИЧНИХ КИСЛОТ У СИРОВИНІ РОСЛИН РОДУ ЛІЛІЙНИК (HEMEROCALLIS L.)
}

\author{
ОС. М. Марчишин ${ }^{1}$, О. В. Зарічанська², Т. О. Щербакова ${ }^{3}$ \\ ДвНЗ «Тернопільський державний медичний університет імені І. Я. Горбачевського МОз україни» ${ }^{1}$ \\ Вінницький національний медичний університет імені М. І. Пирогова ${ }^{2}$ \\ Національний ботанічний сад імені М. М. Гришка НАН УКРАїнИ ${ }^{3}$, Київ
}

РЕЗЮМЕ. Встановлено якісний складта визначено кількісний вміст гідроксикоричних кислоту коренебульбах, листках і квітках двох видів роду Лілійник (Hemerocallis L.). Спектрофотометрично визначено значний вміст суми гідроксикоричних кислот у листках і квітках лілійника буро-жовтого. Методом високоефективної рідинної хроматографії в усіх видах сировини лілійника буро-жовтого (Hemerocallis fulva L.) і лілійника гібридного (Hemerocallis hybrida var. «Stella De Ого») встановлено наявність хлорогенової кислоти.

КЛЮчОВІ СЛОВА: гідроксикоричні кислоти, лілійник буро-жовтий, лілійник гібридний, спектрофотометрія, високоефективна рідинна хроматографія.

Вступ. Пошук перспективних для застосування в медицині рослин $\epsilon$ актуальним завданням сучасної фармацевтичної науки, адже препарати рослинного походження навіть у сучасній медичній практиці займають чільне місце серед усього різноманіття лікарських засобів. Доцільно дослідити культивовані рослини, що наразі використовуються переважно як декоративні елементи та мають достатні сировинні запаси, серед таких види роду Лілійник (Hemerocallis L.).

Для поглибленого фармакогностичного дослідження було обрано два об'єкти - лілійник буро-жовтий (Hemerocallis fulva L.) та лілійник гібридний сорту «Золота зірка» (Hemerocallis hybrida var. "Stella De Oro»). Батьківщиною лілійників вважають Далекий Схід - територію сучасних Японії та Китаю. Лілійник буро-жовтий на території України зростає з кінця XIX століття і з того часу набув широкого розповсюдження завдяки високодекоративним якостям як великих буруватих квіток, так і добре розвинутих темно-зелених розеткових листків. Вид невибагливий до кліматичних умов і на сьогодні широко культивується як декоративно-квітковий, а також у здичавілому вигляді проростає по всій території нашої держави. В науковій і народній медицині рослини роду Лілійник в Україні практично не використовують. Однак у Китаї, Японії, країнах Північної Америки і Сибіру лілійники застосовують як харчові й лікарські рослини [6]. В їжу споживають молоді листки і бутони квіток у свіжому вигляді. Народній медицині цих країн відомі лікувальні властивості кореневих бульб, листків і квіток лілійника бурожовтого, лілійника лимонно-жовтого та лілійника малого. Квітки рекомендують вживати у вигляді настою або настойки для лікування захворювань серцево-судинної системи та шкіри. Листки застосовують як протизапальний, аналгетичний, протисудомний, заспокійливий та антидепресивний засіб. Відвар коренебульб призначають при захворюваннях шлунково-кишкового тракту, підшлункової залози, печінки і жовчного міхура, цукровому діабеті. Коренебульби у вигляді водного витягу застосовують також як жарознижувальний, протизапальний, протинабряковий, протистоцидний і антимікробний засіб [5].

Сортові лілійники, об'єднані під однією видовою назвою лілійник гібридний (Hemerocallis hybrida), з'явились на початку XX століття завдяки роботі ботаніків-селекціонерів, які прагнули отримати рослини з квітками різноманітних форм, розмірів і кольорів. Наразі в Україні також ведуться селекційні роботи з метою отримання вітчизняних високодекоративних видів лілійників. Культивар «Золота зірка» (Hemerocallis hybrida var. "Stella De Ого») отриманий у США в 70-х роках XX століття і $\epsilon$ одним із найбільш поширених у культурі на території України.

Аналіз якісного складу і кількісного вмісту гідроксикоричних кислот (ГКК) сировини лілійника буро-жовтого і лілійника гібридного сорту «Золота зірка» проведено в структурі комплексного фармакогностичного дослідження даних видів лілійників з метою встановлення хімічного складу їх сировини, що в перспективі буде використано при розробці технології отримання сумарних препаратів, дослідження їх токсикологічних і фармакологічних властивостей. Відомо, що гідроксикоричні кислоти проявляють різні фармакологічні ефекти, тому $\epsilon$ необхідним дослідження цих сполук у сировині перспективних для медичного застосування рослин.

Матеріал і методи дослідження. Об'єктами для дослідження були коренебульби, листки і квітки лілійника буро-жовтого (Hemerocallis fulva L.) та лілійника гібридного сорту «Золота зірка» 
Огляди літератури, оригінальні дослідження, погляд на проблему

(Hemerocallis hybrida var. "Stella De Oro»), які заготовляли на науково-дослідній ділянці відділу квітниково-декоративних рослин Національного ботанічного саду імені М. М. Гришка НАН України.

Кількісний вміст суми ГКК у перерахунку на хлорогенову кислоту в рослинній сировині визначено спектрофотометричним методом [1, 2]. Оптичну густину розчину вимірювали на спектрофотометрі Сагу 50 при довжині хвилі 327 нм у кюветі з товщиною шару 10 мм. Для порівняння використовували 20 \% етиловий спирт.

Вміст гідроксикоричних кислот у перерахунку на абсолютно суху сировину у відсотках (X) обчислювали за формулою:

$$
X=\frac{A \cdot V \cdot 51 \cdot 100}{E \cdot m \cdot 1 \cdot(100-W)},
$$

де $A$ - оптична густина досліджуваного розчину;

$V$ - об'єм випробуваного розчину, мл;

$m$ - маса сировини, г;

E- питомий показник поглинання хлорогенової кислоти (531);

W-втрата в масі при висушуванні сировини, \%.

Якісний склад і кількісний вміст гідроксикоричних кислот досліджено методом високоефективної рідинної хроматографії (BEPX) $[3,4]$ на хроматографі Agilent 12003 D LC System Technologies (США), який укомплектований проточним вакуумним дегазатором G1322A, чотириканальним насосом градієнта низького тиску G13111A, автосамплером (автоматичний інжектор) G1329A, термостатом колонок G 1316A, детекторами діодноматричним G1315C та рефрактометричним G1362A. Пробопідготовка рослинної сировини полягала в екстракції подрібненої сировини розчином метанолу 60 \%. Здійснювали оберненофазну хроматографію, використовували хромато- графічну колонку SupelcoDiscovery C18 розміром 250×4,6 мм із сорбентом: силікагель, модифікований октадецильними групами, що має діаметр зерен 5 мкм. Як рухому фазу застосовували сольвент $\mathrm{A}-0,005 \mathrm{~N}$ ортофосфорну кислоту та сольвент В - ацетонітрил. Режим хроматографування: максимальна швидкість подачі рухомої фази 0,7 мл/хв; робочий тиск елюенту - 100-120 bаг (10 000-12 000 кПа); температура термостата колонки - $25^{\circ} \mathrm{C}$; об'єм введеної проби - 5-20 мкл; час хроматографування - 50 хв. Режим елюювання - градієнтний: 0 хв 5 \% “В”, 8 хв $8 \%$ "В”, 15 хв $10 \%$ “B”, 30 хв $20 \%$ “B”, 40 хв $40 \%$ “B”, 41-42 хв 75 \% "В", 43-50 хв 5 \%. Час сканування - 0,6 с, діапазон детектування - 190-400 нм, довжина хвилі - 320 і 330 нм.

Результати й обговорення. Результати спектрофотометричного визначення кількісного вмісту суми ГКК у перерахунку на хлорогенову кислоту в коренебульбах (ЛБЖБ), листках (ЛБЖЛ) та квітках (ЛБЖК) лілійника буро-жовтого і коренебульбах (ЛГБ), листках (ЛГЛ) та квітках (ЛГК) лілійника гібридного наведено в таблиці 1.

Хроматограми гідроксикоричних кислот досліджуваних видів сировини представлено на рисунках 1-6.

Результати визначення ГКК методом ВЕРХ у ЛБЖБ, ЛБЖЛ і ЛБЖК лілійника буро-жовтого та ЛгБ, ЛгЛ і ЛгК лілійника гібридного наведено в таблиці 2.

В усіх досліджуваних об'єктах встановлено наявність хлорогенової кислоти, найбільшу її кількість спостерігали у квітках лілійника бурожовтого (0,641%). У листках лілійника бурожовтого встановлено також наявність та визначено кількісний вміст розмаринової (0,005 \%), ферулової $(0,003 \%)$ і п-кумарової $(0,002 \%)$ кислот; у листках лілійника гібридного - кофейної (0,003 \%)

Таблиця 1. Вміст суми гідроксикоричних кислот у сировині рослин роду Лілійник у перерахунку на абсолютно суху сировину

\begin{tabular}{|c|c|c|c|c|c|c|}
\hline \multirow{2}{*}{ Сировина } & \multicolumn{2}{|c|}{ Коренебульби } & \multicolumn{2}{|c|}{ Листки } & \multicolumn{2}{|c|}{ Квітки } \\
\cline { 2 - 7 } & ЛБЖБ & ЛГБ & ЛБЖЛ & ЛГЛ & ЛБЖК & ЛГК \\
\hline Вміст ГКК, \% & 0,03 & 0,46 & 1,72 & 1,01 & 1,61 & 1,42 \\
\hline
\end{tabular}

Таблиця 2. Вміст гідроксикоричних кислот у сировині рослин роду Лілійник (метод ВЕРХ)

\begin{tabular}{|l|c|c|c|c|c|}
\hline \multirow{2}{*}{ Сировина } & \multicolumn{5}{|c|}{ Вміст ГКК, \% } \\
\cline { 2 - 6 } & $\begin{array}{c}\text { хлорогенова } \\
\text { кислота }\end{array}$ & $\begin{array}{c}\text { розмаринова } \\
\text { кислота }\end{array}$ & $\begin{array}{c}\text { кофейна } \\
\text { кислота }\end{array}$ & $\begin{array}{c}\text { ферулова } \\
\text { кислота }\end{array}$ & $\begin{array}{c}\text { п-кумарова } \\
\text { кислота }\end{array}$ \\
\hline ЛБЖБ & 0,071 & - & - & - & - \\
\hline ЛГБ & 0,120 & - & - & - & - \\
\hline ЛБЖЛ & 0,163 & 0,005 & - & - & 0,002 \\
\hline ЛГЛ & 0,214 & - & 0,003 & - & 0,004 \\
\hline ЛБЖК & 0,641 & - & - & - & 0,012 \\
\hline ЛГК & 0,124 & - & 0,008 & & 0,102 \\
\hline
\end{tabular}


Огляди літератури, оригінальні дослідження, погляд на проблему

та п-кумарової (0,004\%). Кофейна $(0,008 \%)$ та п-кумарова $(0,102 \%)$ кислоти також містяться у квітках лілійника гібридного.

Висновки. 1.Уперше проведено аналіз кількісного вмісту та якісного складу гідроксикоричних кислот у коренебульбах, листках і квітках лілійника буро-жовтого (Hemerocallis fulva L.) та лілійника гібридного сорту «Золота зірка» (Hemerocallis hybrida var. "Stella De Oro») з використанням методів спектрофотометрії та високоефективної рідинної хроматографії.

2. Найбільшим загальним кількісним вмістом гідроксикоричних кислот у перерахунку на хлоро- генову кислоту характеризується сировина лілійника буро-жовтого.

3. Методом ВЕРХ визначено наявність і кількісний вміст хлорогенової кислоти в усіх видах досліджуваної сировини. Найбільший її вміст спостерігають у квітках лілійника буро-жовтого. Надземні органи двох досліджуваних видів лілійника містять п-кумарову кислоту.

4. Отримані результати свідчать про доцільність подальшого фітохімічного аналізу сировини рослин роду Лілійник (Hemerocallis L.), а також перспективність розробки сумарного препарату на їх основі та проведення фармакологічних досліджень.

\title{
ЛІТЕРАТУРА
}

1. Визначення кількісного вмісту гідроксикоричних кислот у сировині дивини звичайної / А. А. Волошина, В. С. Кисличенко, І. О. Журавель, Н. Є. Бурда // Укр. мед. альманах. - 2012. - 15, № 5. - С. 39-40.

2. Рудник А. М. Дослідження фенольних сполук тополі китайської (Populus simonii) / А. М. Рудник, В. М. Ковальов, Н. В. Бородіна // Фармац. часопис. - 2008. - № 4. - С. 37-40.

3. Марчишин С. М. Определение гидроксикоричных кислот в антиаллергическом сборе методом ВЭЖХ [Электронный ресурс] / С. М. Марчишин, С. С. Козачок // Сетевое научное издание : Медицина и образование в Сибири. - 2013. - № 4. - Режим доступа : http://ngmu.ru/ cozo/mos/article/text_full.php?id=1101.

4. Медведев Ю. В. Исследование содержания фенолокислот в лекарственном и пищевом растительном сырье методом ВЭЖХ : автореф. дис. на соискание ученой степени канд. фармац. наук / Ю. В. Медведев. M., 2010. - 24 c.

5. Handbook of Medicinal herbs / J. A. Duke, M. J. Bogenschutz-Godwin, J. Cellier, P. Duke. - 2nd ed. 2002. - P. 246.

6. Que Fei. In vitro and vivo antioxidant activities of daylily flowers and the involvement of phenolic compounds / Fei Que, Linchun Mao, Xiaojie Zheng // Asia. Pac. J. Clin. Nutr. China 310029. US National Library of Medicine. National Institutes of Health. Life Sci. - 2007. - 16, Vol. 25; 75 (6). - P. 196-203.

\section{DETERMINATION OF HYDROXYCINNAMIC ACIDS' QUALITATIVE COMPOSITION AND QUANTITATIVE COTENT IN RAW MATERIALS OF PLANTS OF HEMEROCALLIS L. GENUS}

\author{
@S. M. Marchyshyn ${ }^{1}$, O. V. Zarichanska², T. O. Shcherbakova ${ }^{3}$ \\ SHEI «Ternopil State Medical University by I. Ya. Horbachevsky of MPH of Ukraine»" \\ M. I. Pyrohov Vinnytsia National Medical University ${ }^{2}$ \\ M. M. Hryshko National Botanic Garden ${ }^{3}$, Kyiv
}

SUMMARY. Qualitative composition and quantitative content of hydroxycinnamic acids in modified roots, leaves and flowers of two species of Hemerocallis L. genus have been determined. Spectrophotometrically significant total content of hydroxycinnamic acids in leaves and flowers of tawny daylily (Hemerocallis fulva L.) has been determined. By the method of high-performance liquid chromatography presence of chlorogenic acid has been determined in all kinds of plant raw materials of tawny daylily (Hemerocallis fulva L.) and hybrid daylily (Hemerocallis hybrida var. "Stella De Oro»).

KEY WORDS: hydroxycinnamic acids, tawny daylily, hybrid daylily, spectrophotometry, high-performance liquid chromatography. 